\title{
A morphodynamic model for cohesive sediments transport
}

\section{Um modelo morfodinâmico de transporte de sedimentos coesivos}

\author{
Rodrigo dos Santos Peixoto ${ }^{1}$, Paulo Cesar Colonna Rosman ${ }^{1}$ and Susana Beatriz Vinzon ${ }^{1}$ \\ ${ }^{1}$ Universidade Federal do Rio de Janeiro, Rio de Janeiro, RJ, Brazil \\ E-mails: rodrigo.speixoto@oceanica.ufrj.br (RSP),pccrosman@gmail.com (PCCR),susana@oceanica.ufrj.br (SBV)
}

Received: May 04, 2017 - Revised: August 23, 2017 - Accepted: September 24, 2017

\begin{abstract}
The dynamics of cohesive sediments in natural water bodies is of great importance for coastal engineering. Quite often, it is necessary to assess sedimentological processes in regions where cohesive sediments are prevalent, such as in many harbors. Such assessments poses challenges, especially in quantitative evaluations, as the physics involved in the transport, sedimentation and erosion of cohesive sediments is rather complex. For that, by all means, it is important to have analysis tools capable of computing cohesive sediments dynamics. This paper presents the development of a vertically averaged eulerian transport model for suspended cohesive sediments. Such model is currently available on SisBaHiA ${ }^{\circledR}$, which is a computational modeling system developed and maintained in COPPE/UFRJ. After describing the model implementation, we present a discussion on consistency and validation tests, for each implemented mechanism within the sedimentological process, with a focus in the erosion and sedimentation fluxes. In sequence, we compare model results with the theoretical results and, for some tests, with the results of the simulations performed with the Delft $3 \mathrm{D}^{\circledR}$ and Telemac ${ }^{\circledR}$ modeling systems. These models are similar to the one presented in this paper, and are well accepted and widely used on professional projects and studies. The tests showed that the developed model results were consistent for all the evaluated mechanism, and hence it's positively verified.
\end{abstract}

Keywords: Erosion and sedimentation; Environmental modeling; Sediments transport; Cohesive sediments.

\section{RESUMO}

A dinâmica de sedimentos coesivos em corpos d'água naturais é um tema de grande importância na prática da engenharia costeira, sendo recorrente a necessidade de serem feitos prognósticos sobre esses fenômenos. Devido ao fato da física que envolve o transporte desses sedimentos ser relativamente complexa, o desenvolvimento de estudos e avaliações em projetos de engenharia se mostram um desafio. Assim, é importante que existam ferramentas de análise capazes de descrever os processos sedimentológicos para sedimentos coesivos. Nesse sentido, este artigo apresenta o desenvolvimento de um modelo euleriano 2DH de transporte advectivo-difusivo de sedimentos coesivos em suspensão. Tal modelo está disponível no SisBaHiA ${ }^{\circledR}$, um software computacional de modelagem, desenvolvido e mantido na COPPE/UFRJ. Após a implantação, procedeu-se a etapa de verificação dos mecanismos implementados. Os resultados do modelo foram confrontados com resultados teóricos e, para alguns testes, com os resultados das mesmas simulações feitas com o Delft3D ${ }^{\circledR}$ e o Telemac ${ }^{\circledR}$, que são modelos similares ao desenvolvido neste trabalho. Os testes confirmaram que o modelo desenvolvido apresenta resultados consistentes para todos os mecanismos avaliados, sendo assim positivamente verificado.

Palavras-chave: Erosão e sedimentação; Modelagem ambiental; Transporte de sedimentos; Sedimentos coesivos. 


\section{INTRODUCTION}

The erosion and sedimentation phenomena, caused by sediment transport in natural water bodies, often concern Coastal and Fluvial Engineering. Frequently, an engineer has to make prognostics of these processes in natural environments, for example, to assess the siltation behavior in ports and waterways; to evaluate morphodynamic evolution in coastal, estuarine and riverine environments; or even to assess the impacts on water quality, caused by resuspension phenomena.

In respect to sediments transport, the class of cohesive sediments poses the greatest challenges in studies and engineering projects, because its transport dynamics is rather complex and depends upon many interdisciplinary aspects that have to be taken into account.

For such reason, the existence of analysis tools capable of properly describing the sedimentological processes for fine cohesive sediments is of great importance. In this sense, computational models can be efficient tools for these purposes. For that, they have to support diagnostic and prognostic analysis for a diversity of scenarios in complex environments.

Currently there are many modeling systems available worldwide, each one with its own approach for a proper description of the cohesive sediments dynamics. Among them, perhaps the three best known are Delft3D ${ }^{\circledR}$ (DELTARES, 2016), Telemac-Mascaret ${ }^{\circledR}$ (TELEMAC-MASCARET, 2016) and MIKE ${ }^{\circledR}$ (DHI, 2016).

Nevertheless, any model has its limitations, which can be related to uncertainties of the numerical method used to solve the equations, or even, most importantly, the uncertainties of the mathematical formulations itself, which are responsible for describing the processes involved.

Moreover, certain processes can be described with more accuracy by some models than others, so first of all, to work with modeling requires a deep understanding on the physics of the phenomena of interest, as well as understanding the limitations and data required by the model being used.

\section{On the dynamics of cohesive sediments transport}

In order to understand the cohesive sediments behavior in natural environments, one has to take into account aspects from many knowledge areas, such as physics, chemistry and biology.

Figure 1 presents a rather comprehensive scheme of the main processes regarding the transport dynamics of suspended cohesive sediments.

These set of processes can be divided into four groups: (i) Flocculation, (ii) Settling \& Deposition, (iii) Consolidation, and (iv) Erosion.

Thus, the dynamics that occurs on the water column can be described in a logical sequence of cyclic events that may occur to a particle of fine sediment in suspension:

1. Due to turbulence, the suspended sediment particle will collide with other particles, and due to cohesion they would adhere to each other, forming flocs;

2. Flocs settle faster than a particle alone and hence deposit on the bed;

3. Once in the bed, consolidation processes starts. The consolidation is a rather slow self-weight process, which consists on the expulsion of the interstitial water from the voids of the bed, causing its erosion strength to increase. Chemical and biological processes can also play a role in the strength increase of the soil (GRABOWSKI; DROPPO; WHARTON, 2011). It is worth mentioning that, due to the long period required for relevant consolidation, in the order of many months, this feature is most often a precondition of the bottom sediments. Thus, considering the usual time scales of interest, most models disregard reconsolidation processes;

4. Eventually the local hydrodynamics may be able to erode the sediments at the bed and bring them to suspension, setting the start of a new cycle.

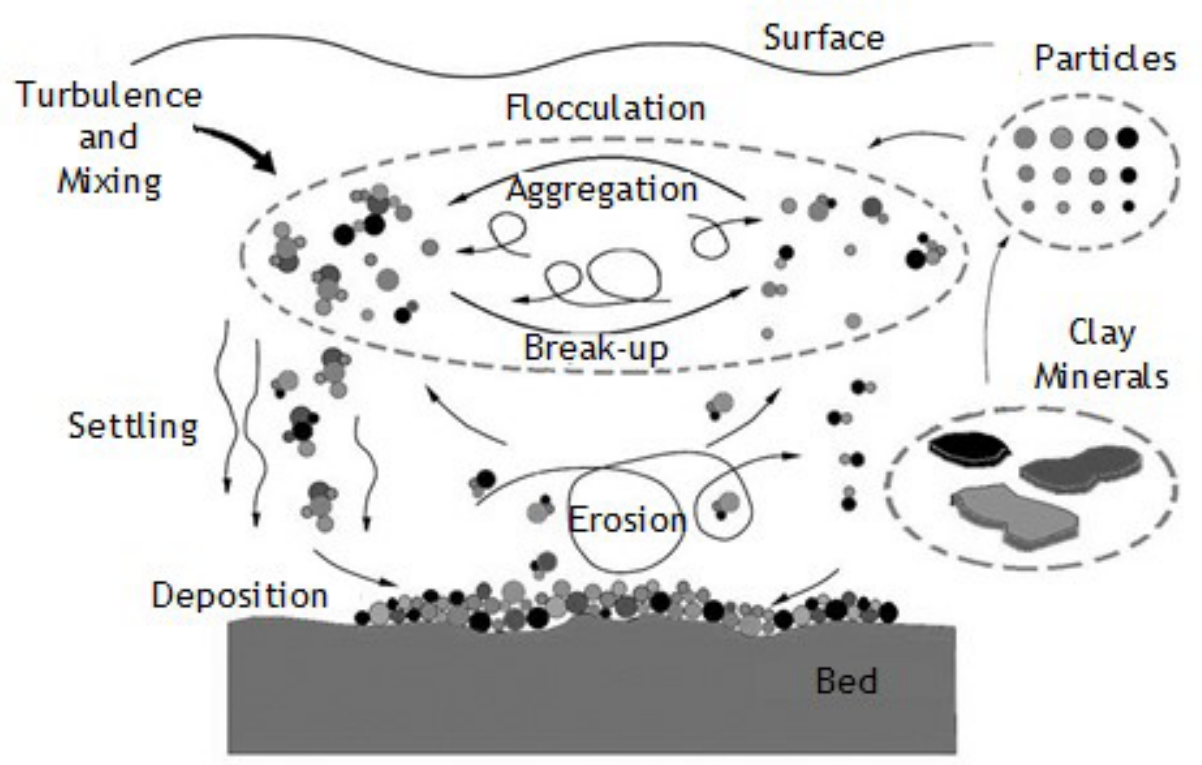

Figure 1. Main processes occurring on the water column and on the bed for cohesive sediments. Adapted from: (MAGGI, 2005). 
Each of these four process groups are by themselves subjects of extensive research on the academia. Basic texts that englobes all these themes can be found in Whitehouse et al. (2000), Winterwerp and Van Kesteren (2004), Partheniades (2009), and Mehta (2013), among others.

On the flocculation process, one can find further information in Overbeek (1952), Dyer (1986), Winterwerp (1998), and Thomas, Judd and Fawcett (1999). About settling and deposition, one might see Kynch (1952), Richardson and Zaki (1954), Krone (1962), Mehta (1986), and Winterwerp (2002). On the consolidation process, further readings are in Toorman (1996) and Roberts et al. (1998). For the erosive process, recommended works are Partheniades (1965), Kandiah (1974), Ariathurai and Arulanandan (1978), and Parchure and Mehta (1985).

\section{OBJECTIVES}

This work describes the sedimentological transport model for suspended cohesive sediments in the SisBaHiA ${ }^{\circledR}$ platform (SISBAHIA, 2016), and its morphodynamic use. Such model improves the erosion and sedimentation mechanisms of the existing Eulerian model, and also accounts for bathymetric evolution on the simulations. The model can also include the effect of bed stratigraphy on the erosion process, which would represent consolidation effects. Thus, it is expected that the model would be able to evaluate erosion and deposition rates, as well as the suspended transport of fine sediments in natural water bodies.

Moreover, the model has passed through a consistency check procedure, following a number of simulations in testing scenarios. These verification tests were developed to analyze each of the implemented mechanisms: erosion, deposition, settling velocity and bottom stratigraphy, as discussed ahead. The model results were compared with analytical solutions and, for specially designed tests, with the results of Delft $3 \mathrm{D}^{\circledR}$ and Telemac ${ }^{\circledR}$, which are similar models already used as engineering tools.

\section{MORPHODYNAMIC MODEL OF COHESIVE SEDIMENTS TRANSPORT}

This section presents the mathematical formulations of the depth averaged eulerian transport model for suspended cohesive sediments. The model hereby presented is currently available at $\mathrm{Sis} B \mathrm{HiA}{ }^{\circledR}$, a professional modeling system registered by COPPE/UFRJ.

The advective-diffusive mechanisms and the boundary conditions definition of the Eulerian model have already been developed and tested on previous occasions, and do not require further discussion.

This paper focuses on the mathematical formulations of the source and sink terms implemented in the model. Such processes comprise the essential mechanisms illustrated in Figure 1, and form a consistent description of sedimentological dynamics in natural environments.

For the sake of contextualization, the next section presents the governing equation for the transport of constituents in fluids. Then the formulations adopted for the erosion and sedimentation mechanisms, which are the focus of this study, are presented.
We emphasize, though, that a full understanding of the sediments transport model require also a basic understanding of the hydrodynamic model from which the sediments model is based on. A full description of SisBaHiA ${ }^{\circledR}$ models, including the hydrodynamic model, is available in the technical reference, (ROSMAN, 2016), in the site (SISBAHIA, 2016).

\section{Transport model governing equation}

The sediment transport model governing equation represents the mass balance of sediments in a water column of unitary horizontal area, and reads as in Equation 1.

$$
\begin{aligned}
& \frac{\partial C}{\partial t}+U \frac{\partial C}{\partial x}+V \frac{\partial C}{\partial y}=-\frac{C}{H}\left(q_{P}-q_{E}+q_{I a}\right)+\sum R+\frac{1}{H} \frac{\partial}{\partial x}\left(T_{x x} \frac{\partial C}{\partial x}+T_{x y} \frac{\partial C}{\partial y}+T_{x t} \frac{\partial C}{\partial t}\right)+ \\
& \frac{1}{H} \frac{\partial}{\partial y}\left(T_{y x} \frac{\partial C}{\partial x}+T_{y y} \frac{\partial C}{\partial y}+T_{y t} \frac{\partial C}{\partial t}\right)
\end{aligned}
$$

Where $C$ is the depth-averaged suspended sediments concentration, $U$ and $V$ are respectively the $x$ and $y$ depth-averaged components of the flow velocity, $H$ is the water column, and the quantities $q_{P}, q_{E}$ and $q_{I}$ are linear discharges $\left[\mathrm{m}^{3} / \mathrm{s} \cdot \mathrm{m}^{2}\right]$ of precipitation, evaporation and infiltration, respectively.

The terms $T_{i j}$ represent the net turbulent dispersive fluxes of Equation 1. These terms are written in $\mathrm{SisBaHiA}^{\circledR}$ as follows (ROSMAN, 2016):

$$
\mathrm{T}_{\mathrm{ij}}=\mathrm{H}[\mathrm{D}_{\mathrm{ij}}+\underbrace{\frac{\Lambda_{\mathrm{j}}^{2}}{12} \mid \frac{\partial \mathrm{u}_{\mathrm{i}}}{\partial \mathrm{x}_{\mathrm{j}}}}_{\mathrm{F}_{\mathrm{ij}}}] ;\left\{\begin{array}{c}
\mathrm{i}=(1,2) \\
\mathrm{j}=(1,2,3)
\end{array}\right.
$$

Where the indexes 1, 2 and 3 represents $x, y$ and $t$, respectively. $D_{i j}$ represents the horizontal dispersion coefficient and $F_{i j}$ are the turbulence filtering terms adopted in SisBaHiA ${ }^{\circledR}$ models (ROSMAN, 2016).

For the case of sediments transport modeling, one admits that the source and sink terms, $\Sigma R$, represents the erosion, $E$, and deposition processes, $D$. Other sources and sinks, $I$, can also be taken into account on the simulations. Therefore, $\Sigma R$, on Equation 1 takes the form:

$$
\sum \mathrm{R}=\frac{1}{\mathrm{H}}(\mathrm{E}-\mathrm{D})+\mathrm{I}
$$

\section{On the erosion and sedimentation mechanisms}

Some aspects differ the dynamics of cohesive sediments from the dynamics of the non-cohesive. Among them, this model considers the following:

- The effect of flocculation processes and hindered settling on the settling velocity of the suspended sediments particles;

- Different critical shear stress thresholds for erosion and deposition;

- The effect of bed stratigraphy in the erosive process. That is, as erosive processes progress down the soil, there are layers of sediments with different erosive threshold 
stresses. Usually, deeper layers are more compact and demand stronger stresses.

The reason to distinguish the erosion critical shear stress, $\tau_{c, E}$, from the deposition critical shear stress, $\tau_{c, D}$, is that many factors, besides the grain's physical characteristics, influences the erosion strength of the bed. Among these variables, the bed consolidation degree plays an important role on the erosion resistance, which can greatly increase the erosion critical shear stress. For more information, Grabowski, Droppo and Wharton (2011) make a comprehensive review regarding the influence of the cohesive sediments properties on its erodibility.

There is an extensive discussion on the academia regarding the applications of the $\tau_{\mathrm{CD}}$ parameter. Further readings on that subject are Maa et al. (2008), Winterwerp (2006), Sanford and Halka (1993) and Krone (1962).

At this point, we must introduce a formal definition for the sedimentation and deposition processes. Sedimentation represents the downward gravity-based flux of suspended sediments, while deposition is a process by which the sediment particles gets in the bed and there remains (KRONE, 1993).

In tri-dimensional numerical simulations, the $\tau_{\mathrm{c}, \mathrm{D}}$ parameter can be disregarded, by the assuming that sedimentation processes are always present in the water column, see Winterwerp (2006). However, disregarding this parameter in depth-averaged models would lead to overestimations on the deposition fluxes (SPEARMAN; MANNING, 2008). That is because depth-averaged models represent vertical fluxes in a parameterized way, and thus it is important to consider a critical shear stress threshold for the deposition process.

It is also possible to take into account the influence of bed stratigraphy on the erosion flux of the sediments in the bed. In this case, the user must give as input to the model, a bed bulk density profile and an erosion critical shear stress profile.

These profiles can vary along the modeling domain, and they simulate the effect of the bed consolidation on the erosion flux. In this regard, deeper layers of sediments have larger bulk density, and hence stronger erosion resistance. Note that in the model, varied consolidation in deeper sediment layers are in the initial conditions. Reconsolidation processes might take from months to years to become relevant, and depend on a multitude of local factors, and for that, the developed model disregards reconsolidation.

\section{Mobility criteria}

The erosion critical shear stress, $\tau_{c, E}$, and the deposition critical shear stress, $\tau_{c, D}$, respectively, are the parameters that define whether on a given hydrodynamic condition there will be erosion in the bed or deposition of the suspended material.

These parameters, especially the erosion critical shear stress can vary considerably according to the sediments physical, chemical and biological characteristics (GRABOWSKI; DROPPO; WHARTON, 2011). This variability is in great part due to cohesion, which creates bonds between particles and also with organic matter, which changes the sediments characteristics and hence makes it more or less susceptible to erosion.
Thus, the application of the mobility criteria consists of simultaneously evaluating the occurrence or not of erosions and/or depositions in the simulation. For this, the algorithm compares the bottom shear stress, $\tau_{0}$, given by the local hydrodynamic condition, with both critical shear stresses, for erosion, $\tau_{c, E}$, and for deposition, $\tau_{c, D}$. If $\tau_{0}$ is greater than $\tau_{c, E}$, erosion occurs. If $\tau_{0}$ is smaller than $\tau_{c, D}$, deposition occurs.

\section{Deposition flux}

If the mobility criteria results in deposition, then the model will calculate the deposition flux, which according to Krone (1962) reads:

$$
\mathrm{D}=\mathrm{W}_{\mathrm{s}} \mathrm{C}_{\mathrm{F}}\left[\frac{\tau_{\mathrm{c}, \mathrm{D}}-\tau_{\mathrm{o}}}{\tau_{\mathrm{c}, \mathrm{D}}}\right]
$$

Where:

$D=$ Deposition flux of sediments in the bed $\left[\mathrm{Kg} / \mathrm{m}^{2} \mathrm{~s}\right]$;

$\tau_{c, D}=$ Critical shear stress for deposition $\left[\mathrm{N} / \mathrm{m}^{2}\right]$;

$\stackrel{c, D}{W}_{s}=$ Settling velocity $[\mathrm{m} / \mathrm{s}]$

$C_{F}=$ Concentration of sediments $\left[\mathrm{Kg} / \mathrm{m}^{3}\right]$, near the bottom.

The model takes into account the effect of formation of flocs in suspension, which increases the settling velocity with the growth of suspended concentration. The formulation describing this process follows:

$$
\mathrm{W}_{\mathrm{S} 1}=\alpha \mathrm{C}^{\mathrm{n}}
$$

Where $C$ is the depth-averaged concentration $\left(\mathrm{Kg} / \mathrm{m}^{3}\right), \alpha$ and $n$ are calibration parameters and $W_{S 1}$ is the settling velocity at the flocculation stage.

For highly concentrated suspensions, greater than a limiting value $C_{H}$, the settling velocity starts to decrease with the concentration increase. This phenomena is called hindered settling, and is due to the hindering effect that one particle causes on the settling of the surrounding particles. At this stage, of concentrations greater than $C_{H}$, the settling velocity is calculated by the formulation of Winterwerp (2002):

$$
\begin{aligned}
& \mathrm{W}_{\mathrm{S} 2}=\mathrm{W}_{\mathrm{S} 0} \frac{(1-\phi)^{\mathrm{m}}\left(1-\phi_{\mathrm{p}}\right)}{1+2.5 \phi} \\
& \mathrm{W}_{\mathrm{S} 0}=\alpha \mathrm{C}_{\mathrm{H}}^{\mathrm{n}} ; \phi=\mathrm{C} / \mathrm{C}_{\mathrm{gel}} ; \phi_{\mathrm{p}}=\mathrm{C} / \rho_{\mathrm{S}}
\end{aligned}
$$

Where:

$W_{S 2}=$ Settling velocity at the hindered settling stage $[\mathrm{m} / \mathrm{s}]$;

$W_{S O}=$ Settling velocity at the concentration $C_{H}[\mathrm{~m} / \mathrm{s}]$;

$C_{H}=$ Threshold concentration between the flocculation and hindered settling stages $\left[\mathrm{Kg} / \mathrm{m}^{3}\right]$;

$C_{g e l}=$ Gelling Concentration $\left[\mathrm{Kg} / \mathrm{m}^{3}\right]$;

$\varrho_{s}^{g e l}=$ Density of the sediment grain $\left[\mathrm{Kg} / \mathrm{m}^{3}\right]$.

Figure 2 illustrates the theoretical behavior of the settling velocity, parameterized by the sediments suspended concentration, using the formulations presented hereby. Note that for concentrations smaller than $C_{H}, W_{S}$ increases with the concentration growth, due to the flocs formation, which settles faster than a single particle of sediment. On the other hand, for concentrations greater then 
$C_{H}, W_{S}$ decreases as concentration increases, due to the hindered settling effect.

The sediment concentration near the bottom, $C_{F}$, is obtained through an analytical profile formulation, given by Winterwerp and Van Kesteren (2004), which is derived from Rouse's analytical profile (ROUSE, 1937). With the formulation of Winterwerp and Van Kesteren (2004), there is no need to determine a reference concentration nor a reference height. One can determine the near-bottom concentration as a function of the depth-averaged concentration calculated by the model.

$\mathrm{C}_{\mathrm{Z}}=\mathrm{C} \frac{\sin (\pi \gamma)}{\pi \gamma}\left(\frac{\mathrm{H}}{\mathrm{z}}-1\right)^{\gamma}$
$\gamma=\frac{\sigma_{\mathrm{T}} \mathrm{W}_{\mathrm{S}}}{\kappa \mathrm{U}_{*}}$

Where:

$C_{Z}=$ Sediment concentration at a height $z$ in the water column $\left[\mathrm{Kg} / \mathrm{m}^{3}\right]$;

$C=$ Depth-averaged sediments concentration $\left[\mathrm{Kg} / \mathrm{m}^{3}\right]$;

$H=$ Water column height $[\mathrm{m}]$;

$\sigma_{T}=$ Prandtl number;

$x=$ Von Kármàn constant.

\section{Erosion Flux}

If the mobility criteria results in erosion, the model will calculate the erosion flux by the Partheniades Equation (ARIATHURAI; ARULANANDAN, 1978):

$\mathrm{E}=\beta_{\mathrm{v}} \rho_{\mathrm{D}}\left[\frac{\tau_{\mathrm{o}}-\tau_{\mathrm{c}, \mathrm{E}}}{\tau_{\mathrm{c}, \mathrm{E}}}\right] ; \rho_{\mathrm{D}}=(1-\mathrm{p}) \rho_{\mathrm{S}}$

Where:

$E=$ Erosion flux of sediments at the bottom $\left[\mathrm{Kg} / \mathrm{m}^{2} \mathrm{~s}\right]$;

$p=$ Porosity;

$\tau_{c, E}=$ Critical shear stress for erosion $\left[\mathrm{N} / \mathrm{m}^{2}\right]$;

$\varrho_{D}=$ Dry density of the bed $\left[\mathrm{Kg} / \mathrm{m}^{3}\right]$;

$\beta_{v}=$ Erosion velocity $[\mathrm{m} / \mathrm{s}]$.

As mentioned before, in $\mathrm{SisBaHiA}^{\circledR}$ the user has the option to represent the effect of bed stratigraphy on the erosion process. In this case, the model considers the bulk density and erosion critical shear stress profiles. Figure 3 illustrates how these profiles evolve as far as successive erosion and deposition occurs on the simulation.

The logic of operation of the profiles is as follows:

1. When erosion at the bed occurs, a parcel of the initial profile, which corresponds to the eroded sediment, is suppressed from the bottom and ressuspended into the water column. Thus, the sediment now exposed at the bed surface has a greater degree of consolidation, which means greater resistance to erosion;

2. On the occurrence of deposition, the bed stratigraphy profile is not restored to the initial profile. That is because the recently deposited sediment holds no relation, in terms of erosion resistance, with the already consolidated sediment previously on the bed. The recently deposited sediments

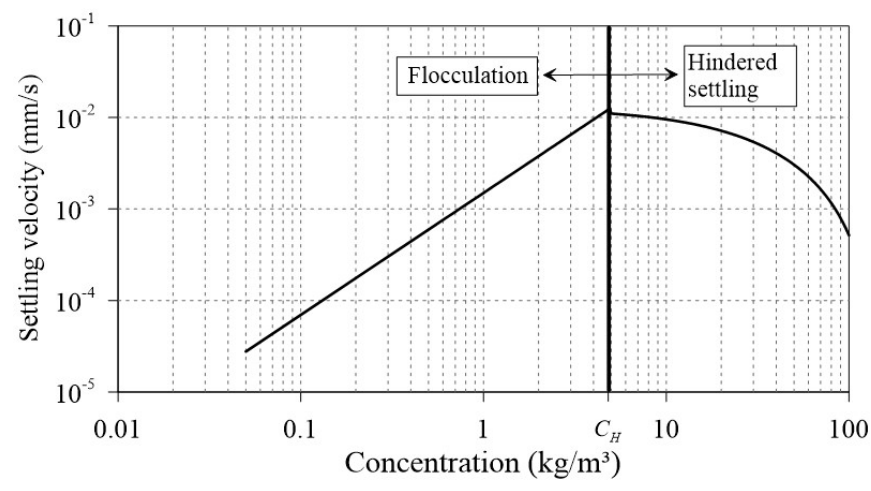

Figure 2. Settling velocity of cohesive sediments, calculated by Equations 5 and 6 , as a function of the suspended concentration.
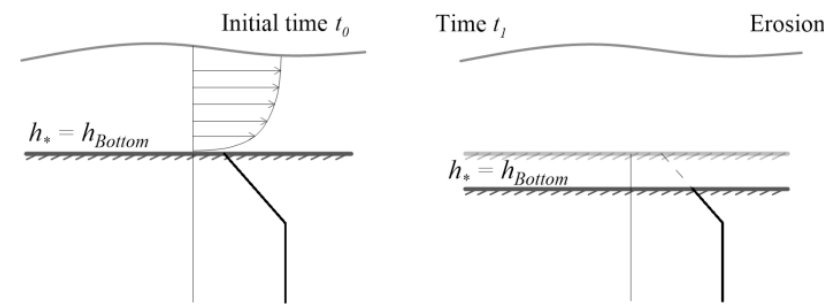

Time $t_{2}$ Deposition

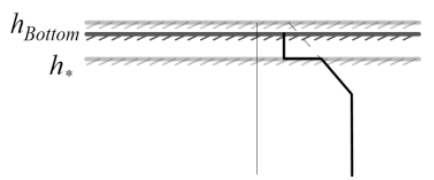

Figure 3. Illustration of the bed stratigraphy profiles evolution during a cycle of erosion and deposition. The profiles pictured on the figure can represent the erosion critical shear profile as well as the bed bulk density profile.

are unconsolidated, therefore are comparatively soft and loose, with a smaller erosion resistance than the sediment of the bed.

So, when deposition occurs, it develops at the bed a first layer of recently deposited soft sediments, and beneath it, a second layer of consolidated sediments. The point at the interface between the layer of recently deposited sediments and the layer of consolidated sediments is defined by a height $h_{*}$, which at the start of the simulation coincides with the local bathymetry, as can be seen at Figure 3. At the first layer, of soft sediments, the bulk density and the erosion critical shear stress $\left(\varrho_{d e p} ; \tau_{c, E d e p}\right)$ are predefined and supposed to be constant. It is worth to recall that the timescale for relevant strength increase of recently deposited sediments is of the order of months, and for that, it is common to disregard such processes.

When erosion occurs, it can happens that the first and the second layers of the bed are eroded, in which case $b_{*}$ is updated to the new bed surface. 


\section{ON THE MODELING SYSTEMS USED FOR VERIFICATION TESTS}

As mentioned before, there are other models similar to the one developed in this paper. However, each model has their peculiarities that need understanding, in order to make consistent comparisons between its mechanisms.

Thus, in order to clarify the theoretical aspects of each model, it follows a brief description of the other modeling systems used at the verification tests of $\mathrm{Sis} B a H i A^{\circledR}$ cohesive sediments model.

\section{Deft3D $^{\circledR}$}

Delft $3 \mathrm{D}^{\circledR}$ is an integrated system of computational models, developed at Deltares ${ }^{\circledR}$, an applied research institute on water resources, based at the Dutch cities of Delft and Utrecht.

This model solves problems in coastal, estuarine and riverine environments. For this, Delft $3 \mathrm{D}^{\circledR}$ has a number of modules, of which the responsible for hydrodynamic and sediments transport simulations is Delft3D-FLOW ${ }^{\circledR}$. It possess $2 \mathrm{DH}$ as well as $3 \mathrm{D}$ models, and uses the finite difference method for the numerical solution of his equations.

It has both cohesive and non-cohesive sediment transport models. In both cases, it uses the eulerian equation of mass balance in a control volume, similar to Equation 1 used at $\mathrm{SisBaHiA}^{\circledR}$, to calculate the advective-diffusive transport.

Further information on the existing formulations and models at Delft3D ${ }^{\circledR}$ are available at the website (DELTARES, 2016).

\section{Telemac-Mascaret ${ }^{\circledR}$}

Telemac-Mascaret ${ }^{\circledR}$ is an integrated system of computational models, developed and maintained by a group of European academic entities, like EDF R\&D (Electricité de France), from France, and HR Wallingford, from the United Kingdom.

It is a numerical model that uses finite elements method, for applications in marine, coastal, estuarine and riverine environments. Telemac-Mascaret ${ }^{\circledR}$ has various modules, of which for the $2 \mathrm{DH}$ cohesive sediments transport simulations, it uses TELEMAC-2D ${ }^{\circledR}$ for the hydrodynamics, and SISYPHE ${ }^{\circledR}$ for the sediments transport.

As for SisBaHiA ${ }^{\circledR}$ and Delft $3 \mathrm{D}^{\circledR}$, Telemac's sediment transport model simulates both cohesive and non-cohesive transport. In both cases, it uses an eulerian equation of mass balance in a control volume, similar to Equation 1, to calculate the advective-diffusive transport.

Further information on the existing formulations and models at Telemac-Mascaret ${ }^{\circledR}$ are available at the website (TELEMAC-MASCARET, 2016).

\section{Comparative summary}

To give an overview of the models attributes, Table 1 shows a comparative summary of the physical mechanisms taken into account by each models used on the verification tests.
Stands out, though, that the hereby presented models' characteristics, regards to the versions we had available for the study. For Delft $3 \mathrm{D}^{\circledR}$ the available version was the open source, and for Telemac ${ }^{\circledR}$ the version 7.0 was used. Also, we are only relating to the mechanisms that are documented in the models' technical reference manuals, which can be accessed through the models website.

The three models use the classical Partheniades-Krone formulations for the erosion and deposition fluxes calculation. However, the erosion flux formulation at SisBaHiA ${ }^{\circledR}$ (Equation 8 ) is slightly different from the one used on the other two models, which is showed on Equation 9:

$\mathrm{E}=\mathrm{M}\left[\frac{\tau_{\mathrm{o}}-\tau_{\mathrm{c}, \mathrm{E}}}{\tau_{\mathrm{c}, \mathrm{E}}}\right]$

In $\mathrm{SisBaHiA}^{\circledR}$ the erosion rate, $M$, is expanded in order to make explicit the dry density of the sediments in the bed, $M=\beta_{\nu} Q_{D}$. That way it is possible to account for the bed density variations, due to stratigraphy, as far as erosion process occurs.

On the settling velocity parameter, Telemac ${ }^{\circledR}$ considers it to be constant and given as input by the user. At $\mathrm{SisBaHiA}^{\circledR}$ and Delft $3 \mathrm{D}^{\circledR}$ this parameter is calculated by the model, considering the effects of flocculation and hindered settling. However, Delft3 ${ }^{\circledR}$ parameterizes the flocculation effect by the salinity, while SisBaHiA ${ }^{\circledR}$ parameterizes it by the suspended concentration. The hindered settling effect is represented in SisBaHiA ${ }^{\circledR}$ by Winterwerp (2002) formulation, Equation 6, while Delft3D ${ }^{\circledR}$ uses Richardson and Zaki (1954) formulation:

$\mathrm{W}_{\mathrm{S} 2}=\left(1-\frac{\mathrm{C}}{\mathrm{C}_{\mathrm{gel}}}\right)^{5} \mathrm{~W}_{\mathrm{S} 0}$

The bed stratigraphy can be represented in the available versions of Delft $3 \mathrm{D}^{\circledR}$ and Telemac ${ }^{\circledR}$, although, its strategies

Table 1. Comparative summary of the physical processes considered by the different modeling systems used in this paper.

SisBaHiA $^{\circledR} \quad$ Delft3D $^{\circledR} \quad$ Telemac $^{\circledR}$

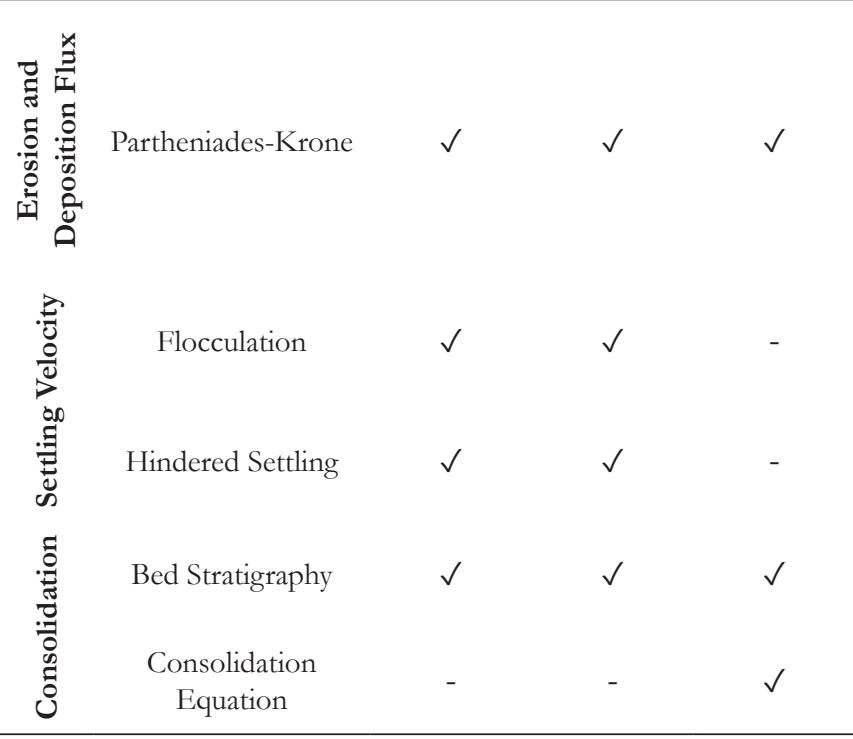


of representation are different from each other and from the one of SisBaHiA ${ }^{\circledR}$. Telemac ${ }^{\circledR}$ also has the option to consider a reconsolidation equation, which would give the time evolution of the stratigraphy profiles.

\section{VERIFICATION TESTS}

In order to check the operation of the model implemented mechanisms, a series of scenarios of testing simulations were carried out, and are presented in this section.

Basically, all the processes considered by the model are inserted on the source and sink terms of Equation 1, which are the Partheniades-Krone formulations, on Equations 4 and 8. The processes are:

- Settling velocity, $W_{s}$, as a function of suspended concentration, representing the effects of flocculation and hindered settling;

- Calculation of the sediments concentration near the bottom;

- The effect of stratigraphy profiles $\left(\tau_{c, E}(\mathrm{z}), \varrho_{D}(\mathrm{z})\right)$ on the erosion process.

So, it is possible to make analysis for the simplest problems, where all the parameters are homogeneous and the processes above are neglected, until more complex situations, where all the implemented mechanisms are taken into account.

Therefore, the following verification tests were developed to evaluate the implemented mechanisms:

- Test of the Erosion Flux - Checks the behavior of Partheniades equation for the erosion flux;

- Tests of the Deposition Flux - There are two tests: the first one checks the behavior of Krone equation for the deposition flux, and the second evaluates the effect of the varying settling velocity and the bottom concentration on the deposition flux;

- Tests of the effect of Bed Stratigraphy - There are two tests: the first one checks the operation of the erosion algorithm at the stratigraphy profiles, and the second evaluates the model behavior on the representation of the mechanism illustrated at Figure 3.

\section{Modeling domain}

All carried out tests employ the same computational domain, changing only the initial and boundary conditions for each test. Figure 4 shows the modeling domain with the mesh used at $\mathrm{SisBaHiA}^{\circledR}$.

The test scenarios were carried out on a straight channel with $12 \mathrm{~km}$ extension and $600 \mathrm{~m}$ width. The bathymetry varied according to each test.

Due to the fact that the tested models use different numerical strategies for the solution of the equations, it is not possible to use the same discretization in all the three models. Instead, it was taken care that the three models uses the same calculation points on its discretization.

\section{Test of the erosion flux}

The verification of erosion flux behavior was given by the observation of the Self-Adjusting principle for fluvial flows in alluvial channels. This test was carried out on $\mathrm{SisBaHiA}^{\circledR}$, Delft3D ${ }^{\circledR}$ and Telemac ${ }^{\circledR}$.

The Self-Adjusting principle dictates that exists a one-way equilibrium relation between the morphology-characterizing variables, or the dependent variables, and the morphology-forming variables, or the independent variables. Further information on the background theory of this principle is available at Blench (1969).

Thus, for this test, the models' initial conditions were a predefined water level gradient and homogeneous bathymetry of $3 \mathrm{~m}$. At the upstream boundary, it was given a constant discharge of $450 \mathrm{~m}^{3} / \mathrm{s}$ and at the downstream boundary the water level was fixed at the elevation $0 \mathrm{~m}$.

These conditions simulates the situation of a channel that was in static equilibrium and then suddenly suffers a discharge increase. Initially, it causes an increase in the water level gradient, which misaligns the bed slope with the water level slope, and consequently turns the system into a non-equilibrium condition.

By the Self-Adjusting principle the establishment of a new equilibrium condition is expected with the realignment between the water level gradient and the bed slope.

\section{Tests of the deposition flux}

To verify the deposition flux behavior in the model, two tests were carried out:

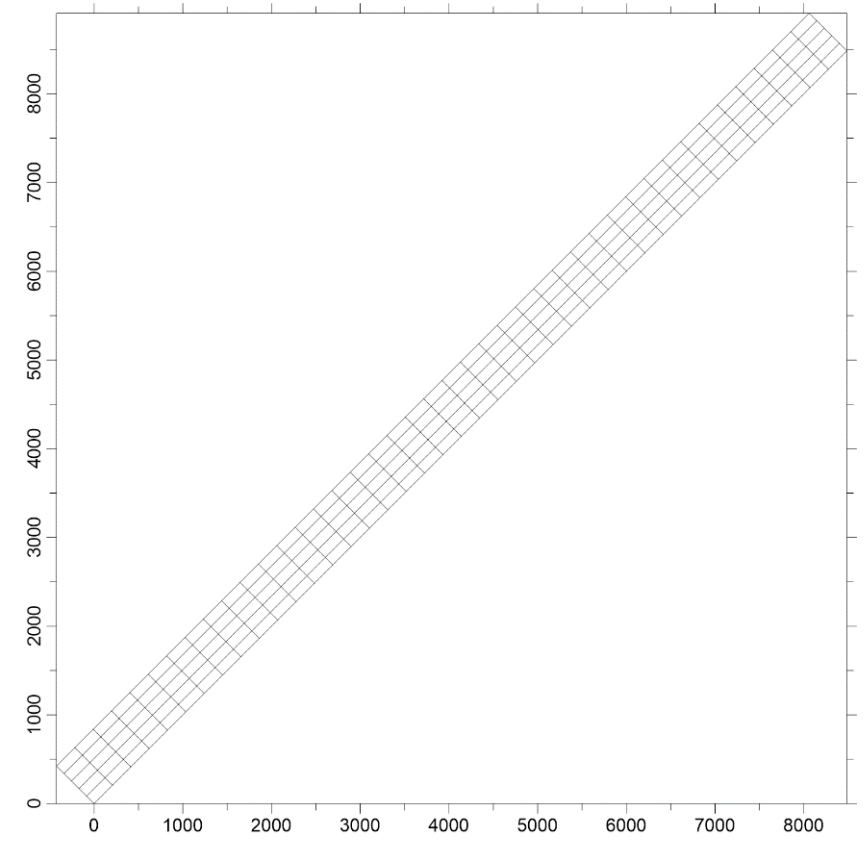

Figure 4. Modeling domain of the verification tests and discretization used at $\mathrm{Sis} B \mathrm{HHiA}{ }^{\circledR}$. The axes represents the mesh's local coordinates in meters. 
- Test 1: Checks Krone Equation behavior, considering $W_{\text {S }}$ to be constant and $C_{F}$ to be equal to the depth-averaged sediments concentration;

- Teste 2: Verifies the effects of considering $W_{S}$ to be variable and $C_{F}$ to be calculated by Equation 7, on the deposition flux behavior.

\section{Test 1: Krone equation}

The idealized scenario for this test was a no-flow condition, on which at the simulation beginning there was a certain homogeneous suspended sediment concentration for the entire modeling domain. So, because there are no hydrodynamic velocities, in the course of simulation deposition will occur, and the suspended sediments concentration will decay until zero.

For this described situation, the governing equation (Equation 1), is reduced to:

$$
\frac{\partial \mathrm{C}}{\partial \mathrm{t}}=-\frac{\mathrm{D}}{\mathrm{H}}=-\frac{\mathrm{W}_{\mathrm{S}} \mathrm{C}}{\mathrm{H}} \underbrace{\left[\frac{\tau_{\mathrm{c}, \mathrm{D}}-\tau_{\mathrm{o}}}{\tau_{\mathrm{c}, \mathrm{D}}}\right]}_{\mathrm{T}^{*}}
$$

As there is no hydrodynamic flow, $\tau_{0}$ is zero and hence the term $T *$ is equal to 1 . Thus, the governing equation is further reduced to:

$$
\frac{\partial \mathrm{C}}{\partial \mathrm{t}}=-\frac{\mathrm{W}_{\mathrm{S}}}{\mathrm{H}} \mathrm{C}
$$

The above equation has an analytical solution, producing the following expression, where $C_{0}$ is the initial suspended sediments:

$$
\mathrm{C}(\mathrm{t})=\mathrm{C}_{0} \mathrm{e}^{-\left(\mathrm{W}_{\mathrm{S}} / \mathrm{H}\right) \mathrm{t}}
$$

The resulting sedimentation height, from the deposition of all the initially suspended material can be analytically determined as well:

$$
\Delta \mathrm{h}=\frac{\mathrm{C}_{0} \mathrm{H}}{\rho_{\mathrm{D}}}
$$

This test was carried out with the three models, and considered as initial conditions homogeneous water level and bathymetry, which were equal to 0 and $3 \mathrm{~m}$, respectively. On the sediment transport model, the settling velocity was set to $0.75 \mathrm{~mm} / \mathrm{s}$, the dry density was set to $250 \mathrm{~kg} / \mathrm{m}^{3}$ and the initial suspended sediment concentration was set to $5 \mathrm{~kg} / \mathrm{m}^{3}$.

Thus, the analytical solution for the time evolution of the suspended sediment concentration at every point in the model, and the final sedimentation height are:

$$
\mathrm{C}(\mathrm{t})=5 \mathrm{e}^{-0.00025 \mathrm{t}} \quad ; \quad \Delta \mathrm{h}=0.06 \mathrm{~m}
$$

\section{Test 2: Effect of settling velocity and bottom concentration}

After the verification of Krone Equation on Test 1, the effect, on deposition flux, of the bottom concentration and the settling velocity varying with the suspended concentration, was tested.
The simulated conditions for this test are similar to Test 1. Two different scenarios were developed:

- Scenario 1 [Ws variable $\&$ Depth-averaged Concentration]: Considers the settling velocity to vary with the suspended concentration, and the bottom concentration to be equal to the depth-averaged concentration;

- Scenario 2 [Ws variable \& Bottom Concentration]: Considers the settling velocity to vary with the suspended concentration, and the bottom concentration calculated by Equation 7. As only SisBaHiA ${ }^{\circledR}$ includes this mechanism, it is not possible to compare with the other models.

\section{Tests of the effect of bed stratigraphy}

The representation mechanism of the bed stratigraphy effect is evaluated in this section. For this, two tests were carried out with $\mathrm{SisBaHiA}{ }^{\circledR}$ :

- Test 1: Checks the operation of the erosion algorithm at the stratigraphy profiles. Thus, the hydrodynamic conditions were set up in such way that erosion flux would be constant in the course of simulation;

- Test 2: Checks the operation of the mechanism illustrated in Figure 3, of successive erosions and depositions at the bed with stratigraphy profiles.

\section{Test 1: Constant erosion}

A characteristic of consolidated cohesive sediment beds is that erosion strength increases as deep as erosion goes into the bed. On this situation, Partheniades equation (Equation 8) now has three time-dependent variables: the bottom shear stress $\tau_{\mathrm{o}}$, the critical shear stress for erosion $\tau_{c, E}$ and the bed dry density $\varrho_{D}$.

For convenience, it was considered in this test that variations on the bed dry density could be neglected and the erosion critical shear stress profile is linear.

$$
\begin{aligned}
& \tau_{\mathrm{o}}(\mathrm{t})=\rho_{\mathrm{w}} \frac{\mathrm{g}}{\mathrm{C}_{\mathrm{h}}^{2}} \mathrm{U}(\mathrm{t})^{2} \\
& \tau_{\mathrm{c}, \mathrm{E}}(\mathrm{t})=\gamma \mathrm{h}^{\prime}(\mathrm{t})+\tau_{\mathrm{E} 0}
\end{aligned}
$$

Where:

$U=$ Flow velocity $[\mathrm{m} / \mathrm{s}]$;

$\tau_{0}=$ Bottom shear stress $\left[\mathrm{N} / \mathrm{m}^{2}\right]$;

$C_{b}=$ Chézy coefficient;

$b^{\prime}=$ Depth on the bed, referenced to the initial bathymetry $[\mathrm{m}]$; $\gamma=$ Angular coefficient $\left[\mathrm{N} / \mathrm{m}^{3}\right]$;

$\tau_{\mathrm{E} 0}=$ Initial erosion critical shear stress at the top of the profile $\left[\mathrm{N} / \mathrm{m}^{2}\right]$.

The rate of change of the depth on the bed h' with time is a function of erosion flux:

$$
\frac{\partial h^{\prime}}{\partial \mathrm{t}}=\frac{\mathrm{E}}{\rho_{\mathrm{D}}}
$$


As the erosion flux and the bed dry density were considered to be constant in this test, there is no time-dependency for these variables, so the expression for $b$ ' as function of time is:

$$
h^{\prime}(t)=\frac{E}{\rho_{D}} t
$$

Working with Equations 8,16 and 18 it is possible to get to an expression for the flow velocity $U$ as function of time, which would make the erosion flux to be constant.

$\mathrm{U}(\mathrm{t})=\left\{\frac{\mathrm{C}_{\mathrm{h}}^{2}}{\rho_{\mathrm{w}} \mathrm{g}}\left[\frac{\mathrm{E}+\beta_{\mathrm{v}} \rho_{\mathrm{D}}}{\beta_{\mathrm{v}} \rho_{\mathrm{D}}-\mathrm{E}}\right]\left[\gamma \frac{\mathrm{E}}{\rho_{\mathrm{D}}} \mathrm{t}+\tau_{\mathrm{E} 0}\right]\right\}^{\frac{1}{2}}$

This test scenario was built following the above mathematical deductions. Figure 5 shows the flow velocity time-series, calculated by Equation 19, used as boundary condition in the model, as well as the erosion critical shear stress profile used as initial condition for the bed.
Test 2: Successive erosions and depositions

The aim of this test is to check the stratigraphy profiles evolution during an erosion-deposition-erosion cycle. Figure 3 presents the expected behavior for this mechanism.

To reproduce it, a velocity time-series was given to the model as the upstream boundary condition. At the beginning, the velocities are great enough to erode the consolidated bed until a certain depth. After that point, the flow ceases and the suspended sediments deposits on the bed, forming an upper bed layer of unconsolidated material.

Then the flow restarts, however with velocities smaller than at the beginning of simulation, capable of eroding only the upper layer of the bed with unconsolidated material.

Figure 6 shows the velocity time series at the model upstream boundary with its respective bottom shear stresses, and the initial conditions at the bed given as an erosion critical shear stress profile. It was also assumed that the erosion critical shear stress of the recently deposited material and the deposition critical shear stress were equal to $0.05 \mathrm{~N} / \mathrm{m}^{2}$.
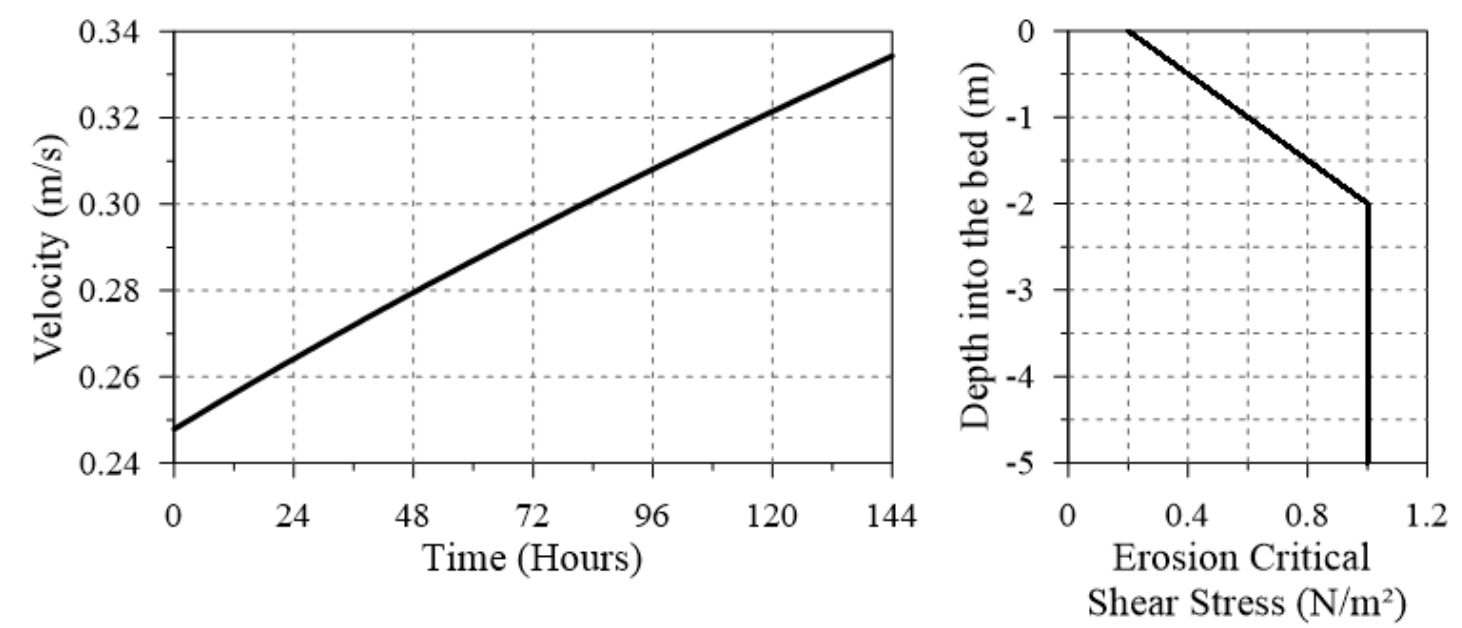

Figure 5. Flow velocity time-series used in the model upstream boundary (left); Erosion critical shear stress profile given as initial condition for the bed (right).
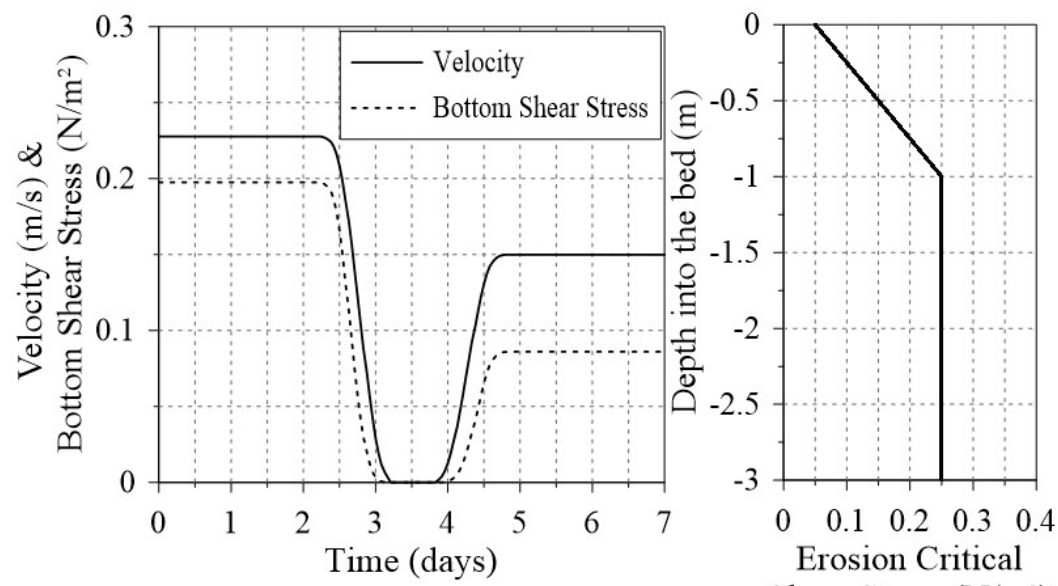

Shear Stress $\left(\mathrm{N} / \mathrm{m}^{2}\right)$

Figure 6. Velocity time series at the model's upstream boundary and its respective bottom shear stresses (Left); Erosion critical shear stress profile given at the bed (Right). 


\section{RESULTS}

This section presents the results of the previously described verification tests.

\section{Test of the erosion flux}

As expected, the three models reached a new equilibrium condition, predicted by the Self-Adjusting principle. Figure 7 shows $\mathrm{SisBaHiA}{ }^{\circledR}$ results for the alignment between the water level and the bed level longitudinal profiles. Results for the other models are similar.

It is remarkable the alignment of the profiles, indicating the establishment of a new equilibrium condition at the channel.

Figure 8, Figure 9 and Figure 10 shows the three models results for the time evolution of the bottom until the equilibrium condition achievement.

It is noticeable the great agreement between the three models results. There were no significant differences on the time to achieve the equilibrium condition or on the calculations of the erosion heights.

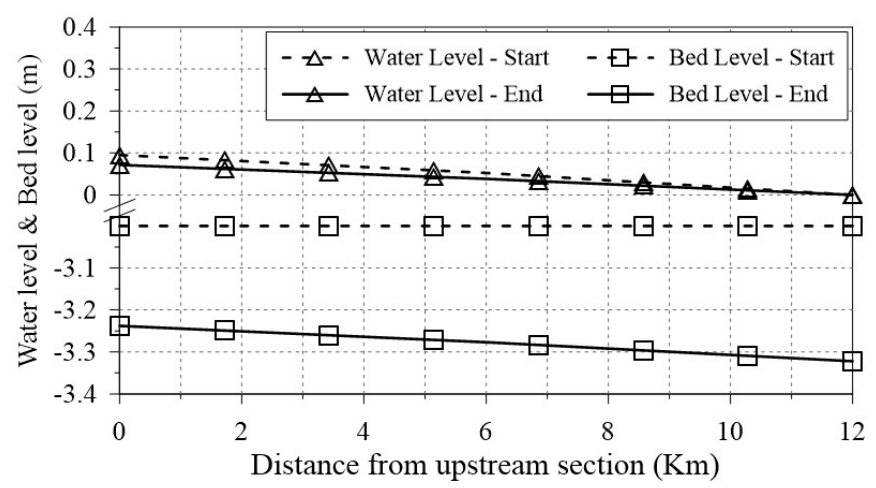

Figure 7. Water level and bed level longitudinal profiles, calculated by $\mathrm{Sis} \mathrm{BaHiA}{ }^{\circledR}$, for the start and the end of the simulation.

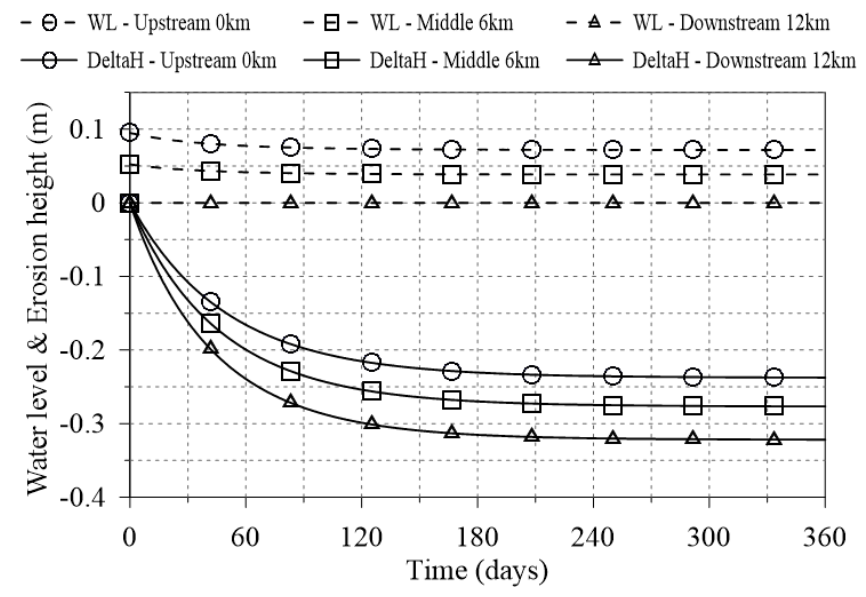

Figure 8. $\mathrm{SisBaHiA}^{\circledR}$ results for the time evolution of the bed and the water level at three points in the model: upstream $(0 \mathrm{~km})$, middle $(6 \mathrm{~km})$ and downstream $(12 \mathrm{~km})$.
On the erosion heights, those slight differences observed are due to the different strategies used by each model to parameterize the roughness coefficient.

For that reason, the water level gradients, applied as initial conditions, could not be exactly the same on the three models. Different water level gradients would produce different equilibrium conditions, which is coherent with the observed results.

Therefore, the erosion mechanism, implemented on SisBaHiA ${ }^{\circledR}$ is in accordance with the expected, and so it is positively checked.

\section{Test of the deposition flux}

This section presents the results of the two verification tests of the deposition flux mechanisms.

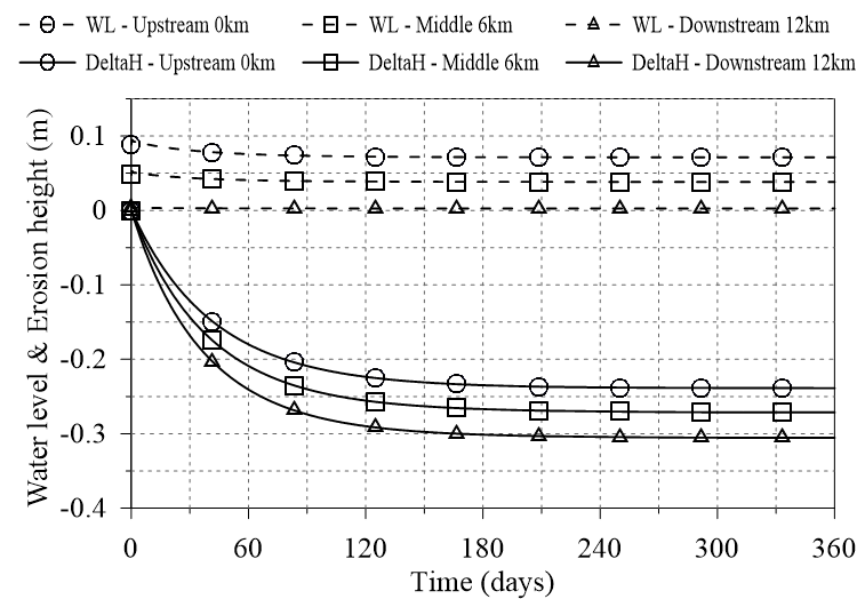

Figure 9. Delft $3 \mathrm{D}^{\circledR}$ results for the time evolution of the bed and the water level at three points in the model: upstream $(0 \mathrm{~km})$, middle $(6 \mathrm{~km})$ and downstream $(12 \mathrm{~km})$.

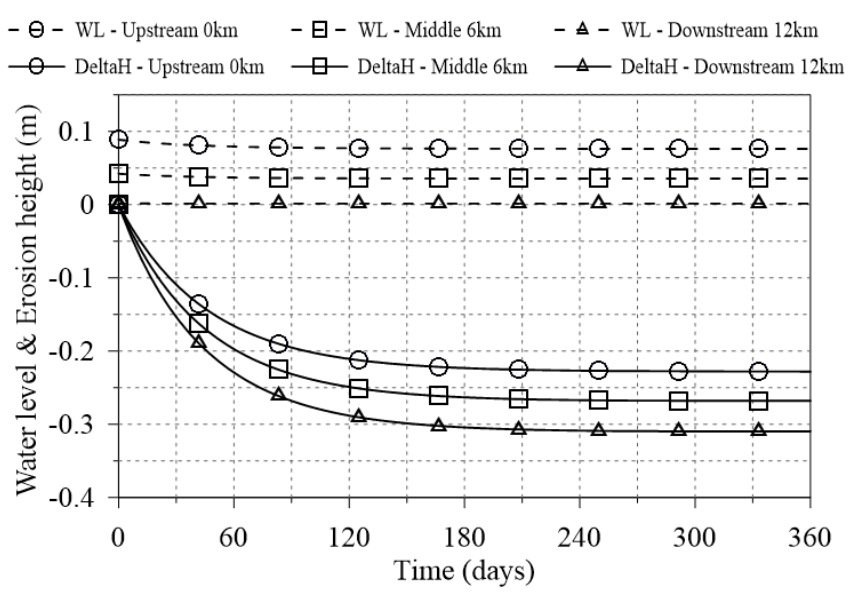

Figure 10. Telemac ${ }^{\circledR}$ results for the time evolution of the bed and the water level at three points in the model: upstream $(0 \mathrm{~km})$, middle $(6 \mathrm{~km})$ and downstream $(12 \mathrm{~km})$. 
Test 1: Krone equation

Figure 11 shows the results for the concentration decay from the analytical solution and the simulations with the three models.

As expected, SisBaHiA ${ }^{\circledR}$, Delft $3 \mathrm{D}^{\circledR}$ and Telemac ${ }^{\circledR}$ presented very close results to the analytical solution. Moreover, Table 2 shows the great agreement between $\mathrm{SisBaHiA}{ }^{\circledR}$ results, for the final sedimentation height, and the analytical solution, as well as to the other models results.

That said, the suspended sediments deposition process, represented by Krone equation, was successfully implemented on $\mathrm{SisBaHiA}{ }^{\circledR}$.

\section{Test 2: Effect of settling velocity and bottom concentration}

Figure 12 shows $\mathrm{SisBaHiA}^{\circledR}$ results for the concentration decay, simulated on the two scenarios of Test 2, together with Test 1 results for concentration decay.

By the analysis of Scenario 1 and 2 results, and confrontation with Test 1 , it is remarkable the flocculation effect on the increase of settling velocity, which is the faster decay of the concentration at Scenarios 1 and 2 than at Test 1 for the beginning of simulation.

This is an expected result because at the flocculation stage settling velocity increases as far as concentration increases, so at the beginning of simulation, settling velocity was higher at Scenarios 1 and 2 than at Test 1 because of the high concentrations. As concentration decays, settling velocity starts to decrease as well, and then a shift occurs, where concentration decays faster at Test 1 than at Scenarios 1 and 2.

It is also remarkable that at Scenario 2, concentration decays much faster, at the beginning of simulation, than at Scenario 1 and Test 1 . This reflects the effect of considering the bottom concentration, which is greater than the depth-averaged concentration, and makes the deposition flux (Equation 4) to be greater in this case than at the tested cases with depth-averaged concentrations.

\section{Tests of the effect of bed stratigraphy}

This section presents the results of the two developed tests to check the operation of the mechanism that represents the bed stratigraphy effect on the erosion process.

\section{Test 1: Constant erosion}

With the initial and boundary conditions, showed in Figure 5, set up in the model, it is expected that SisBaHiA ${ }^{\circledR}$ calculates a constant erosion flux, equal to $10^{-4} \mathrm{~kg} / \mathrm{m}^{3}$, and an erosion height varying linearly with time, as showed in Equation 18.

Figure 13 compares the simulation results with the theoretical results for this test. There is great agreement between them, showing that $\mathrm{Sis} \mathrm{BaHiA}{ }^{\circledR}$ mechanism for erosion in stratified beds is working as expected.

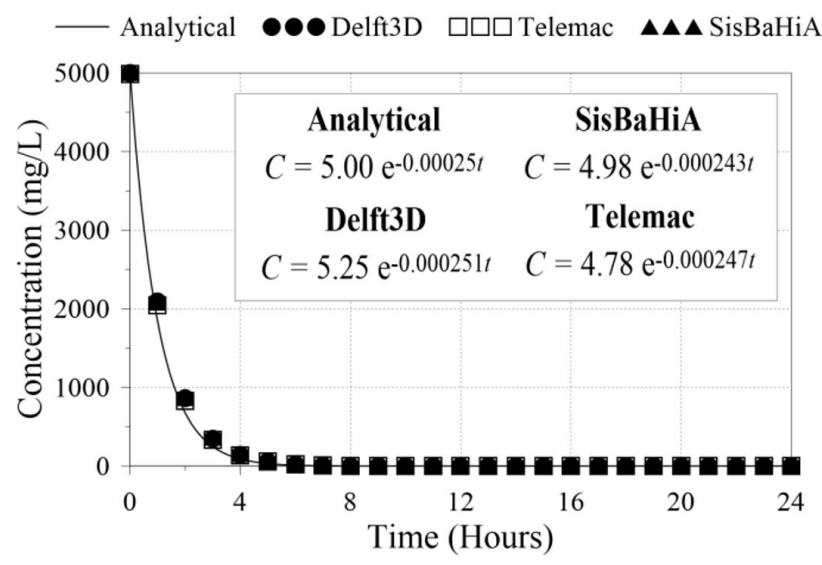

Figure 11. Results of the concentration decay, from the analytical solution and the simulations with SisBaHiA ${ }^{\circledR}, \mathrm{Delft} \mathrm{D}^{\circledR}$ and Telemac $^{\circledR}$.

Table 2. Final sedimentation height, obtained by the three models simulations. Theoretical result $=0.06 \mathrm{~m}$.

\begin{tabular}{cc}
\hline Models & Sedimentation height $(\mathrm{m})$ \\
\hline Delft3D $^{\circledR}$ & 0.05914 \\
Telemac $^{\circledR}$ & 0.05926 \\
SisBaHiA $^{\circledR}$ & 0.06000 \\
\hline
\end{tabular}

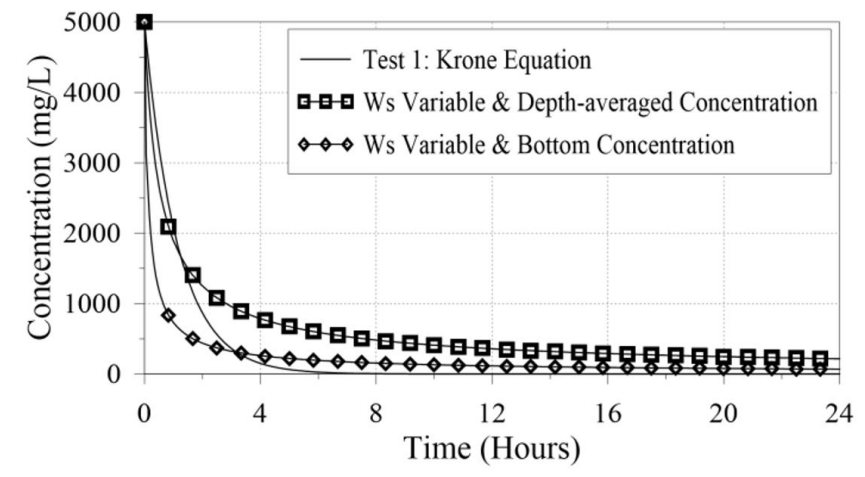

Figure 12. Depth-averaged concentration decay simulated on the two scenarios of Test 2, and comparison with Test 1 results.

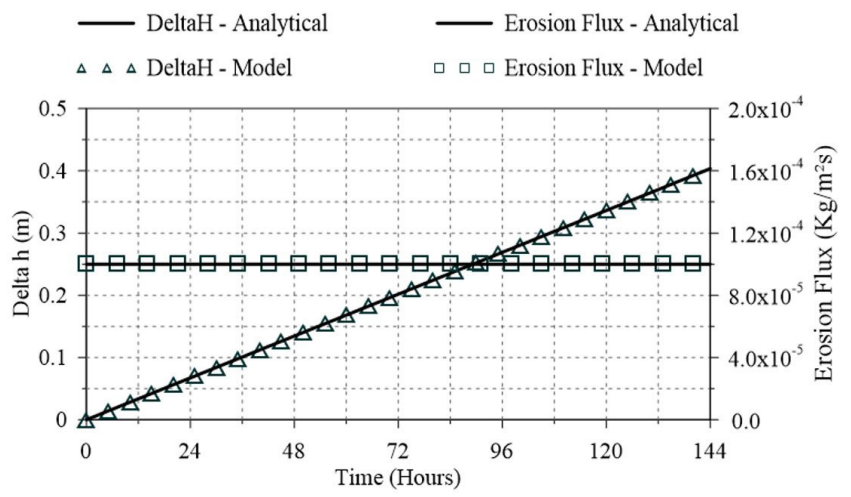

Figure 13. Comparison between model and theoretical results for the test of stratified beds erosion mechanism. 


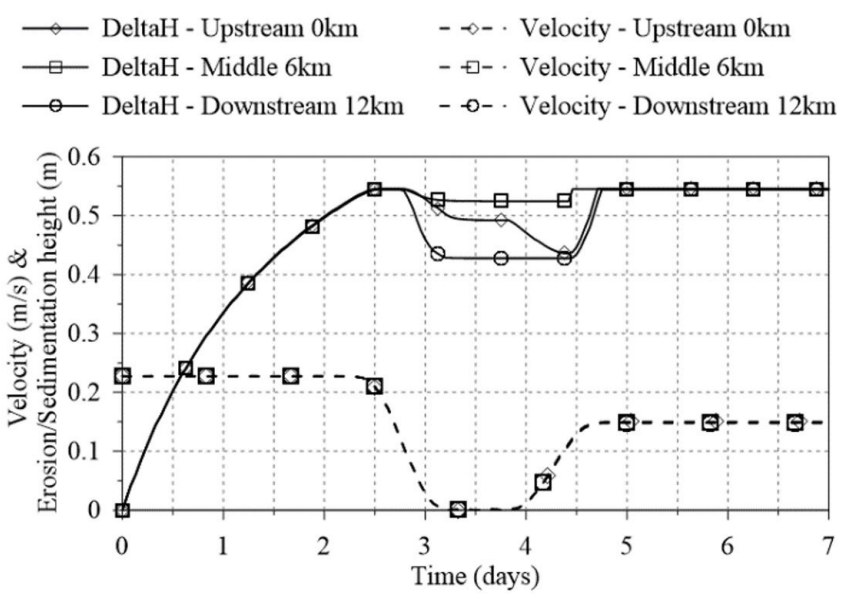

Figure 14. Bathymetry variations and flow velocities for the three model observation points: Upstream $(0 \mathrm{~km})$, Middle $(6 \mathrm{~km})$ and Downstream $(12 \mathrm{~km})$.

\section{Test 2: Successive erosions and depositions}

Figure 14 shows the time series for the bathymetric variations and flow velocities for the three model observation points.

The results analysis shows that the model reproduces the expected behavior, which consists of erosion on the first stage of simulation, followed by deposition at the second stage, caused by the flow stagnation, and subsequent resuspension of the recently deposited sediments at the third stage, when the flow restarts.

At the resuspension stage, it is noticeable that erosion ceases at the exact point where it had stopped, at the end of the first stage of simulation. It means that the entire soft sediment upper layer has been resuspended and the consolidated sediment layer became exposed again to the flow. However, because the flow is less intense at the third stage of simulation than at the first stage, it is unable to mobilize the consolidated sediment.

It is also noticeable that on fourth day of simulation, deposition ceases at the Upstream section, and soon after that, it restarts. Deposition stops because when the flow ceases, all the sediments in suspension at the water column, settles to the bed leaving no more material available for sedimentation. Right after the flow begins to be reestablished, at the end of fourth day, the suspended sediments input returns, and so it becomes available for deposition again. Thus, at this point, deposition restarts, and continues until the flow gains enough energy to support the sediments in suspension

Thus, in light of the results for this test and for Test 1 , it is perceivable that the effect of bed stratigraphy on sediment transport produced results within the expected by the theory and, therefore, it can be said that this mechanism is working correctly.

\section{CONCLUSION}

As demonstrated in the verification tests, the presented model is capable of correctly representing the sedimentological processes for suspended cohesive sediments, illustrated in Figure 1, as well as the advective-diffusive transport in suspension and the bottom morphodynamic evolutions.
The model results in the verification tests showed consistency with theory for all the implemented mechanisms. In addition, its accuracy was very similar to those of Delft $3 \mathrm{D}^{\circledR}$ and Telemac ${ }^{\circledR}$, which are widely used softwares for research and engineering studies.

On top of that, the fact that this model is available at a national platform such as $\mathrm{SisBaHiA}^{\circledR}$, which is relatively easy to obtain and to operate, in comparison with the other models, is an additional advantage. Therefore, the developed model constitutes of a tool with great potential for environmental studies and engineering projects applications.

\section{REFERENCES}

ARIATHURAI, R.; ARULANANDAN, K. Erosion rate of cohesive soils. Journal of the Hydraulics Division, v. 104, n. 2, p. 279-283, 1978.

BLENCH, T. Mobile-bed Fluviology: a regime theory treatment of canals and rivers for engineers and hydrologists. Edmonton: University of Alberta Press, 1969.

DELTARES. Delft3D Open Source Community. 2016. Disponivel em: <https://oss.deltares.nl/web/delft3d>. Acesso em: 12 Junho 2016.

DHI. MIKE powered by DHI. 2016. Disponivel em: < https://www. mikepoweredbydhi.com/>. Acesso em: 12 Junho 2016.

DYER, K. R. Coastal and estuarine sediment dynamics. 2th ed. California: Wiley, 1986. v. 22.

GRABOWSKI, R. C.; DROPPO, I. G.; WHARTON, G. Erodibility of cohesive sediment: Importance of sediment properties. EarthScience Reviews, v. 105, n. 3-4, p. 101-120, 2011. http://dx.doi. org/10.1016/j.earscirev.2011.01.008.

KANDIAH, A. Fundamental aspects of surface erosion of cohesive soils. 1974. Ph.D. Thesis - University of California, Davis, Califórnia, 1974.

KRONE, R. B. Flume estudies of the transport of sediment in estuarial shoaling processes. Berkeley: University of California, 1962.

KRONE, R. B. Sediment revisited. In: MEHTA, A. J. Nearshore and estuarine cohesive sediment transport. Washington: American Geophysical Union, 1993. p. 108-125.

KYNCH, G. J. A theory of sedimentation. Transactions of the Faraday Society, v. 48, n. 0, p. 166-176, 1952. http://dx.doi.org/10.1039/ tf9524800166.

MAA, J. P.-Y.; KWON, J.-I.; HWANG, K.-N.; HA, H.-K. Critical bed-shear stress for cohesive sediment deposition under steady flows. Journal of Hydraulic Engineering, v. 134, n. 12, p. 5, 2008. http://dx.doi.org/10.1061/(ASCE)0733-9429(2008)134:12(1767).

MAGGI, F. Flocculation dynamics of cohesive sediments. 2005. Ph.D Thesis - Delft University of Technology, Delft, 2005.

MEHTA, A. J. Characterisation of cohesive sediment properties and trasnport processes in estuaries. In: MEHTA, A. J. Estuarine 
cohesive sediment dynamics, lecture notes in coastal and estuarine studies. New York: Springer, 1986. cap. 15, p. 290-325.

MEHTA, A. J. An introduction to bydraulics of fine sedimente transport. 1th ed. Singapura: World Scientific, 2013.

OVERBEEK, J. T. Kinetics of flocculation. Colloid Science, v. 1, p. 278-300, 1952.

PARCHURE, T. M.; MEHTA, A. J. Erosion of soft cohesive sediments deposits. Journal of Hydraulic Engineering, v. 111, n. 10, p. 1308-1326, 1985. http://dx.doi.org/10.1061/(ASCE)07339429(1985)111:10(1308).

PARTHENIADES, E. Erosion and deposition of cohesive soils. Journal of the Hydraulics Division, v. 91, n. 1, p. 105-139, 1965.

PARTHENIADES, E. Cohesive sediments in open channels. 1th ed. Oxford: Butterworth-Heinemann, 2009.

RICHARDSON, J. F.; ZAKI, W. N. The sedimentation of a suspension of uniform spheres under conditions of viscous flow. Chemical Engineering Science, v. 3, n. 2, p. 65-73, 1954. http://dx.doi. org/10.1016/0009-2509(54)85015-9.

ROBERTS, J.; JEPSEN, R.; GOTTHARD, D.; LICK, W. Effects of particle size and bulk density on the erosion of quartz particles. Journal of Hydraulic Engineering, v. 124, n. 12, p. 1261-1267, 1998. http://dx.doi.org/10.1061/(ASCE)0733-9429(1998)124:12(1261).

ROSMAN, P. C. C. Referência técnica do SisBaHiA. Rio de Janeiro: SisBaHiA; UFRJ, 2016.

ROUSE, H. Modern conceptions of the mechanics of fluid turbulence. Transactions of the American Society of Civil Engineers, v. 102, n. 1, p. 436-505, 1937.

SANFORD, L. P.; HALKA, J. P. Assessing the paradigm of mutually exclusive erosion and deposition of mud, with examples fom Chesapeake Bay. Marine Geology, v. 114, n. 1-2, p. 37-57, 1993. http://dx.doi.org/10.1016/0025-3227(93)90038-W.

SISBAHIA. SisBaHiA-COPPE/UFRJ. 2016. Disponivel em: < http:/ / www.sisbahia.coppe.ufrj.br>. Acesso em: 12 Dezembro 2016.

SPEARMAN, J.; MANNING, A. J. On the significance of mud transport algorithms for the modelling of intertidal flats. In: KUSUDA, T.; YAMANISHI, H.; SPEARMAN, J.; GAILANI, J. Sediment and ecobydraulics: INTERCOH 2005. Elsevier, 2008. p. 411-430. E-book.
TELEMAC-MASCARET. Open Telemac-Mascaret. 2016. Disponivel em: <http://www.opentelemac.org/>. Acesso em: 12 Junho 2016.

THOMAS, D. N.; JUDD, S. J.; FAWCETT, N. Flocculation modelling: a review. Water Research, v. 33, n. 7, p. 1579-1592, 1999. http://dx.doi.org/10.1016/S0043-1354(98)00392-3.

TOORMAN, E. A. Sedimentation and self-weight consolidation: general unifying theory. Geotechnique, v. 46, n. 1, p. 103-113, 1996. http://dx.doi.org/10.1680/geot.1996.46.1.103.

WHITEHOUSE, R; SOULSBY, R.; ROBERTS, W.; MITCHENER, H. J. Dynamics of estuarine muds: a manual for pratical applications. London: Thomas Telford, 2000.

WINTERWERP, J. C. A simple model for turbulence induced flocculation of cohesive sediment. Journal of Hydraulic Research, v. 36, n. 3, p. 309-326, 1998. http://dx.doi.org/10.1080/00221689809498621.

WINTERWERP, J. C. On the flocculation and settling velocity of estuarine mud. Continental Shelf Research, v. 22, n. 9, p. 13391360, 2002. http://dx.doi.org/10.1016/S0278-4343(02)00010-9.

WINTERWERP, J. C. On the sedimentation rate of cohesive sediments. In: MAA, J. P.-Y.; SANFORD, L. P.; SCHOELLHAMER, D. H. Estuarine and coastal fine sediment dynamics: INTERCOH 2003. Amsterdam: Elsevier, 2006. p. 209-226.

WINTERWERP, J. C.; VAN KESTEREN, W. G. M. Introduction to the physics of cohesive sediment dynamics in the marine environment. 1 th ed. Amsterdam: Elsevier, 2004.

\section{Authors contributions}

Rodrigo dos Santos Peixoto: Model conception and implementation in $\mathrm{SisBaHiA}^{\circledR}$; literature review; conception and development of the test scenarios; writing of the paper.

Paulo Cesar Colonna Rosman: Technical advising on the model conception and implementation; contribution on the writing of the paper.

Susana Beatriz Vinzon: Technical advising on the cohesive sediments dynamics and conception of the model; contribution on the writing of the paper. 